\title{
Application of learning model with responsibility strategies in learning process at junior high school
}

\section{Yusida Imran}

Universitas Muhammadiyah Sumatera Barat, Padang - Indonesia, (yusiimran@gmail.com)

\begin{abstract}
This research is motivated by the existence of the phenomenon related with the problem of moral quality of students who are associated with learning, the lack of ability of learners in creativity. This study aims to develop a learning model with BMB-3 transformative strategy in the learning process at Junior High School in Padang City. This research is a model development research using ADDIE pattern. The location of this research is conducted in three junior high schools, public and private schools in Padang city, namely SMP Negeri 1 (accredited A), SMP 32 (accredited B), and SMP Angkasa Padang (accredited C), each class VIII. The instrument used in the form of the questionnaire, and data analysis is done quantitatively and qualitatively. Based on the results of research that has been done found the application of transformative strategyBMB3 effectively used to improve the learning process.
\end{abstract}

Keywords: model, transformative strategy BMB-3, junior high school.

\section{Introduction}

Today the quality of learning issues become a very important issue in the world of education in Indonesia (Sudarsana, 2016). Such conditions are identified through various problems such as an adolescent brawl (Alhamri \& FAKHRURROZI, 2012);(Aprilia \& Indrajati, 2014);(Pudjiastuti, 2010);(Tarigan \& Siregar, 2013);(Rahmania \& Suminar, 2012);(Oesman, 2012), drug problems (Iswanti, Suhartini, \& Supriyadi, 2010); (Menthan, 2013);(T. Santoso \& Silalahi, 2012), free sex (Cynthia, 2011);(Aini, 2011);(Magdalena, 2010), moral decline and lack of respect for students to parents and teachers in the majority of schools and communities (F. A. Santoso, 2014).

The phenomenon within the field has not seen any influence of learning outcomes that achievement can ensure changes in student attitudes are expected. The application of learning model using transformative strategies is expected to be applied in the learning process to improve the quality of learning in school (Sanjaya, 2016). The study was conducted on three subjects, Bahasa Indonesia, PKN and IPA. This is done because the researchers see the process of learning, especially the strategy used by teachers, so for each lesson does not become obstacles to be distinguished by type of lesson, because it does not reduce the content of the subject matter taught so far, so that any lesson will be possible and applicable. The emphasis is on how the ability of an educator to be able to prepare themselves in planning the learning, ranging from making RPP to implement the learning 
processes itself, according to the material of each meeting upon the subject and then includes elements of responsible learning strategies in the implementation.

Learners also need the touch of a professional teacher (Wijaya, 2012); (Rusilowati, Hartono, \& Supriyadi, 2012), interest and exemplary in the learning process. Based on the above discussion how important the meaning of education that is designed and implemented systematically conducted by an educator. This must be realized comprehensively the linkage of several supporting elements with each other, to achieve the expected learning objectives, so that the realization of a complete education by developing the three capabilities of learners in the form of cognitive, affective and psychomotor. As illustrated below.

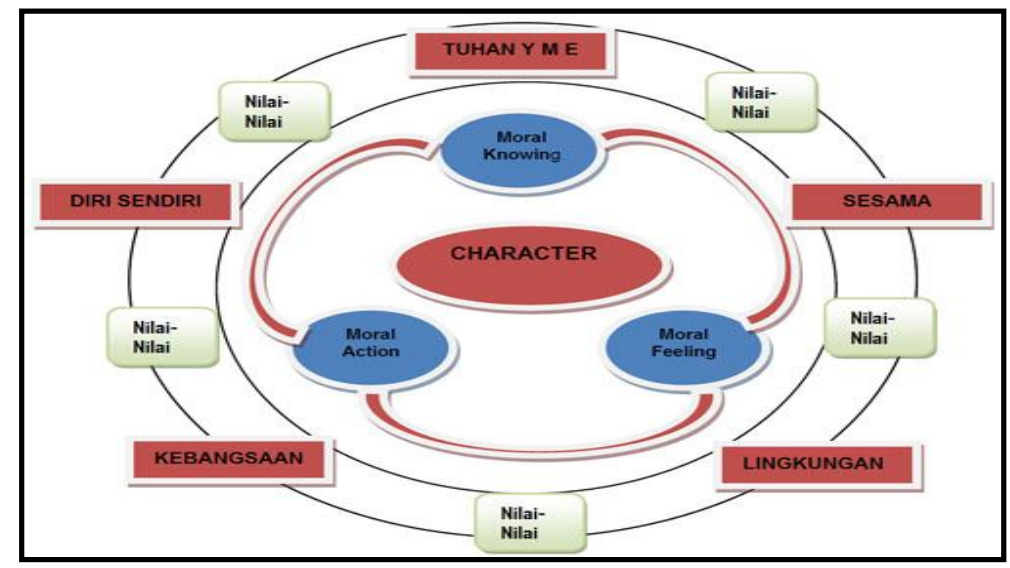

Picture 1. Character Education Scheme

(source: depdikbud)

A number of approaches and classifications of education put forward by experts are trying to summarize the various components that drive human behavior. In a cognitive moral approach, for example, it is taught by providing insight, knowledge, and understanding of moral teachings that are expected to produce good behavior. In social behavior approaches, education is taught through the regulation of behavior in social relationships in everyday life. According to Wena, the use of strategies in learning is necessary because it can simplify the learning process to achieve optimal results because it implements contextual learning (Wena, 2009). Elaine B. Johnson said that when students can relate the content of academic subjects, such as language, PKN, IPA, and others, with their own experience, they find meaning, and the meaning gives them a reason to learn (Johnson, 2002).

Furthermore, according to Dollarhide T. Collette on teaching strategy and lesson planning, an effective classroom set up on awards, both personal and intellectual, personal appreciation has been presented in respect of everyone (Dollarhide, Gibson, \& Saginak, 2008). Selection of schools based on accreditation such as SMPN 1 accreditation A, SMPN 32 with accreditation B while SMP Angkasa accreditation $\mathrm{C}$, so it is considered to represent junior high schools in the city of Padang. Furthermore, in relation with the learning process, in addition to teachers, and counselors, education requires a strategy in the implementation of the learning process, for which researchers try to implement BMB3 strategy that includes the implementation of responsible strategies. This strategy is important to improve understanding and mastery of the material on learners. The purposes of this research are: 1) the development of a learning model that enables learners responsibly by using existing materials; 2) the model's training and practice intended by the teacher; 3 ) the intended model is considered feasible to be used by potential users and related parties. This study is expected to improve the quality of learners with optimal results as we expect. 


\section{Method}

This research is included within the type of research application is part of (research and development), which is a systematic exercise by combining between basic research and applied research, which aims to find solutions or create something better and find science. This research is for the development as a model of giving BMB3 strategies by the teacher for the subjects that are his responsibility, in this case the subjects of Bahasa Indonesia, PKN, IPA and Guidance and Counseling.

This series of model development activities uses the "ADDIE" Model Theory approach, which includes the development stages of Analysis, Design, Development, Implementation, and Evaluation (Dick \& Carey, 1996);(Molenda, 2003). Incorrect models need to be revised to meet standards as a powerful learning model for achieving educational goals.

\section{Results and Discussion}

The results showed after the development of the model found that the effectiveness of the implementation of the transformative strategy described in the following table:

Table 1. Recapitulation of Implementation Effectiveness Transformative Strategy-BMB3

\begin{tabular}{ccccc}
\hline School & Subject & \multicolumn{3}{c}{ Percentage (\%) } \\
\cline { 3 - 5 } & & $\mathbf{A}$ & $\mathbf{B}$ & $\mathbf{C}$ \\
SMPN 1 Padang & Indonesia Language & 2,89 & 27,06 & 91,40 \\
& Natural Science & 2,79 & 27,41 & 85,58 \\
& Civic education & 3,15 & 24,71 & 95,12 \\
\multirow{2}{*}{ SMPN 32 Padang } & Indonesia Language & 3,03 & 30,59 & 83,95 \\
& Natural Science & 2,27 & 23,53 & 86,98 \\
\multirow{2}{*}{ SMP Angkasa Lanud } & Civic education & 2,69 & 22,35 & 89,77 \\
Padang & Indonesia Language & 11,85 & 16,47 & 90,93 \\
& Natural Science & 9,24 & 17,65 & 89,30 \\
& Civic education & 4,09 & 22,35 & 88,84 \\
\hline
\end{tabular}

Information:

A : Percentage improvement between before and after implementation of BMB3 learning strategy to learners

B : Percentage increase between before and after implementation of BMB3 learning strategy by a teacher

C : Percentage of implementation of BMB3 learning strategy in teacher by the observer.

In order to see the results of the implementation of the BMB3-Transformative Strategy in the learner, before and after the implementation of this strategy, an analysis of the questionnaire was obtained, achieving an average increase of $8 \%$ for all subjects in three schools. To see the result of the implementation of Transformative-BMB3 strategy to Teachers, before and after the execution of the strategy is done the analysis of the questionnaire dispersion, achieved an average increase achievement of $27 \%$. Meanwhile, the observer's evaluation of teachers in the implementation of BMB3 Transformative strategy reached $87 \%$ compared to before the training implementation using BMB3transformative strategy.

Based on the comparison of achievement results from the implementation of the new model, it is seen that the learning process using Transformative-BMB3 strategy tends to be better or more ideal in its implementation, before and after being given assessment and analyzed to see the effectiveness of using this strategy in the classroom with limited test in three schools different and three subjects. From the results of field observation also seen a change in attitude and activities of students who tend 
to be more excited and interested in the learning process so that the results of learning tend to increase.

\section{Discussion}

\section{The Nature of Education}

Education is an independent and universal science. By following the study and systematic description. Educational science contains in it components of ontology, epistemologies, and axiology. According to Prayitno, these three components form an independent and universal science (Prayitno \& Khaidir, 2011). Learning is a process that takes place within a person, which gives birth to thinking and takes place through the experience and action power over the environment in which he is located so that there is a change of behavior that is positive or better than before.

Learners

Understanding the learner is any person who receives influence from a person or group of people who run educational activities. While the special understanding is the immature person submitted to the responsibility of the educator.

\section{Educators}

Educator in the Provisions of The Law of the National Education System Number 20 of 2003 Articles 1 is a qualified teaching force as teachers, lecturers, counselors, tutors, widyaswara, tutors, instructors, facilitators and other designations in accordance with the specificity, and participate in the implementation of education (Indonesia, 2003). Furthermore, Chapter XI of article 39 also mentions that educators are professionals in command of planning and implementing the learning process, assessing learning outcomes, conducting mentoring and training, and community service. Effective teachers can be realized with a good understanding of learners, both an understanding of their potential and individual differences. According to Elliott N Stephen et al that the potential and diverse cultural backgrounds of the various students should be the teacher's concern in fostering harmonious social interaction so that the learning process becomes effective (Elliott \& Travers, 1996). Educators must also realize meaningful learning for learners, because according to Novak (1986) the higher the learning process aims to meaningful learning. Then the independence of learners will be higher.

\section{Educational Objectives}

In the National Education System Act (SISDIKNAS) no. 20 Year 2003 Articles 2 and 3 reads (Indonesia, 2003): national Education based on Pancasila and the Constitution of the Republic of Indonesia 1945. National Education functions to develop the ability and from the character and civilization of dignified nation in order to educate the nation. Thinking, Being, Acting, and Responsible (BMB3) Strategy.

1. Dimension BMB3

BMB3 is the dynamics that exist in the human self who God has given us, even need to be developed so that the energy of intelligent character can be realized. From the study of human life daily we can know the five dynamics of life that is: thinking, feeling, behaving, acting, and responsible.

The connection between intelligent characters with BMB3 is actually interesting. Apparently, no human life is not filled with demands of intelligent character and BMB3. Along with that for human life to be developed then the conditions of the realization of intelligent character and dynamics BMB3 must be sure. If the condition of the intelligent character and BMB3 is low, it can be ascertained that the life of such a human group is less advanced, and vice versa. As the name of dynamics of course, BMB3 appears first, and intelligent character is the BMB3 content. Without the dynamics of a content will not be realized. Without contents, dynamics can run even if not content 
or void. Thus BMB3 dynamics is the earliest and most basic "sign of life." Without BMB3, there will be no sign of life, even if life becomes frozen, stagnant, and zero.

2. Transformative Learning Strategy and BMB3

Through the process of learning, the task of educators not just transfers or transplant the subject matter to the learners, but rather change or transform themselves from the original condition to the new conditions through the discussion of learning materials. If only the transactional process (transplanting) is used, the learning material may indeed reach the learners but is feared less useful to them. Alternatively, at least, it just becomes a matter of memorization without meaning. Conversely through the process of transformative (change) educators deliberately change themselves learners in accordance with the purpose of education / learning using the learning materials in question. By using BMB3 dynamics, the learners' self is transformed from the initial state to the new condition, in accordance with the meaning of the definition and the learning dimension.

Based on this case can be taken the example as follows: On PKN subjects with the material of State Governance RI. For educator-guided practices it is always oriented to the BMB3 strategy which begins with the educator's explanation of the subject and then proceeds by activating learners through how they think according to the material described at the meeting and linking it with the educational goals of spiritual, religious, personality and so on, as well as the second BMB3 that is felt again associated with the purpose of the six fruit until finally the material delivered is always associated with all elements BMB3 and also the six objectives of education contained in the Act have been outlined. Thus, the importance of learners' activities and the creativity of educators to be able to carry out the learning process with the atmosphere and the learning process becomes real and there is a close relationship between the materials, strategies and educational goals that must be implemented through the learning process.

Slightly different for its application in counseling service, where for subject matter for field of study done by using an information service by a teacher of BK by raising selected topic, for example, about juvenile delinquency, or school discipline whose execution keeps using BMB3 strategy and oriented with the educational purpose. The process was sequential as due by teachers from the field of study.

The learning condition for the application of the strategy can be described as follows:

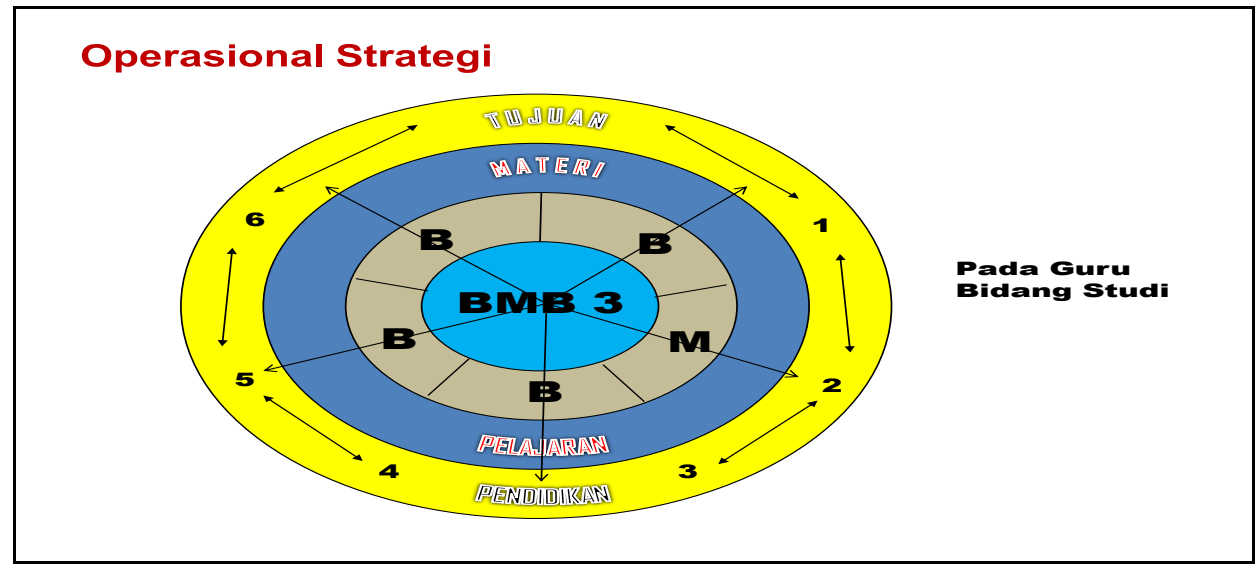

Picture 3. Operational Strategy on the Subject

(Source: Research Design)

Information:

- BMB3: Thinking, Feeling, Being, Acting, Responsible

- Lesson Material: in accordance with subject matter material

- Educational Objectives: 

1. Religious Spiritual Power
2. Self-Control
3. Personality
4. Inteligence
5. Your Majesties

\section{Consclusion}

Transformative Strategy-BMB3 it could improve the effectiveness of learning held by teachers and followed by students who become respondents / sample research. This study has resulted in a learning model that enables BMB3 students for science, civics, and Indonesian lessons in the form as a learning model with Transformative Strategy-BMB3. As for through the preparation of a more targeted RPP. This new strategy is more effective and useful in enabling students to follow the learning process than the learning strategies held by teachers at previous times. Through training of teachers and to make RPP and its implementation based on Transformative-BMB3 strategy in applying classroom learning process. The quality into the learning process will increase.

\section{References}

Aini, L. N. (2011). Hubungan Pemahaman Tingkat agama (Religiusitas) dengan Perilaku Seks Bebas pada Remaja di SMAN 1 Bangsal Mojokerto. Jurnal Keperawatan, 1(01).

Alhamri, A., \& FAKHRURROZI, M. M. (2012). Kecerdasan Emosi Pada Remaja Pelaku Tawuran.

Aprilia, N., \& Indrajati, H. (2014). Hubungan antara kecerdasan emosi dengan perilaku tawuran pada remaja laki-laki yang pernah terlibat tawuran di SMK "B" Jakarta. Jurnal psikologi pendidikan dan perkembangan, 3(1), 1-11.

Cynthia, T. (2011). Konformitas kelompok dan perilaku seks bebas pada remaja. Jurnal Ilmiah Psikologi, 1(1).

Dick, W., \& Carey, L. (1996). Instructional design models: Belmont, California: Brook and Cole.

Dollarhide, C., Gibson, D., \& Saginak, K. (2008). New counselors' leadership efforts in school counseling: Themes from a year-long qualitative study. Professional School Counseling, 11(4), 262271.

Elliott, S. N., \& Travers, J. F. (1996). Educational psychology: Effective teaching, effective learning: Brown \& Benchmark Madison, WI.

Indonesia, P. R. (2003). Undang-undang Republik Indonesia nomor 20 tahun 2003 tentang sistem pendidikan nasional.

Iswanti, D. I., Suhartini, S., \& Supriyadi, S. (2010). Koping keluarga terhadap anggota keluarga yang mengalami ketergantungan narkoba diwilayah kota Semarang. Nurse Media Journal of Nursing, 1(1).

Johnson, E. B. (2002). Contextual teaching and learning: What it is and why it's here to stay: Corwin Press.

Magdalena, M. (2010). Melindungi anak dari seks bebas: Grasindo.

Menthan, F. (2013). Peranan Badan Narkotika Nasional Kota Samarinda dalam Penanggulangan Masalah Narkoba di Kalangan Remaja Kota Samarinda. Ejournal Administrasi Negara, 1(2), 544557.

Molenda, M. (2003). In search of the elusive ADDIE model. Performance improvement, 42(5), 34-37.

Oesman, A. T. (2012). Fenomena Tawuran sebagai Bentuk Agresivitas Remaja. Skripsi, 8(1).

Prayitno, \& Khaidir, A. (2011). Model Pendidikan Karakter-Cerdas. Padang: UNP Press.

Pudjiastuti, W. (2010). Strategi mengatasi masalah kesehatan dan lingkungan hidup di pemukiman kumuh lewat program pemasaran sosial. Hubs-Asia, 9(2).

Rahmania, A. M., \& Suminar, D. R. (2012). Hubungan antara persepsi terhadap kontrol orangtua dengan kecenderungan perilaku delinkuensi pada remaja yang pernah terlibat tawuran. Jurnal Psikologi Pendidikan dan Perkembangan, 1(3), 1-7. 
Rusilowati, A., Hartono, H., \& Supriyadi, S. (2012). Pengembangan Model Pembelajaran Better Teaching and Learning Berkarakter untuk Membekali Kompetensi Pedagogi Mahasiswa Calon Guru. Jurnal Penelitian Pendidikan, 29(2).

Sanjaya, D. H. W. (2016). Penelitian tindakan kelas: Prenada Media.

Santoso, F. A. (2014). Pengaruh Perhatian Orang Tua Di Rumah Terhadap Prestasi Belajar Siswa Di Bidang Studi Pendidikan Agama Islam Di Sma Mujahiddin Surabaya. UIN Sunan Ampel Surabaya.

Santoso, T., \& Silalahi, A. (2012). Penyalahgunaan Narkoba Di Kalangan Remaja: Suatu Perspektif. Jurnal Kriminologi Indonesia, 1(1).

Sudarsana, I. K. (2016). Peningkatan Mutu Pendidikan Luar Sekolah Dalam Upayapembangunan Sumber Daya Manusia. Jurnal Penjaminan Mutu, 1(1), 1-14.

Tarigan, S. K., \& Siregar, A. R. (2013). Gambaran Penalaran Moral pada Remaja yang Tinggal di Daerah Konflik. Psikologia: Jurnal Pemikiran dan Penelitian Psikologi, 8(2).

Wena, M. (2009). Strategi pembelajaran inovatif kontemporer: Jakarta: Bumi Aksara.

Wijaya, M. (2012). Pengembangan model pembelajaran e-learning berbasis web dengan prinsip ePedagogy dalam meningkatkan hasil belajar. Jurnal Pendidikan Penabur, 11(19), 20-27. 